\title{
Activity of Disinfectants related to Food Hygiene and Sanitation
}

\author{
F R Lima' , S Ahmed ${ }^{2}$
}

\section{Abstract}

Objectives : To observe the activity of disinfectants related to food hygiene and sanitation and to determine the germicidal effect of those disinfectants against various microorganisms adhered to different surface materials in relation with time and concentration.

Materials and Methods : The study was carried out in the Institute of Nutrition and Food Science (INFS) of Dhaka University, Dhaka during February-September 2002. The disinfectants were sodium hypochlorite $(\mathrm{NaOC} 1)$ and calcium hypochlorite $\mathrm{Ca}(\mathrm{OCI})_{2}$. Minimum Inhibitory Concentration (MIC), Qualitative and Quantitative suspension test, Phenolic co-efficient test and Germicidal effect of $\mathrm{NaOC} 1$ and $\mathrm{Ca}(\mathrm{OCI}) 2$ against $\boldsymbol{E}$ coli and Staph aureus on different surface materials were tested. Surface materials of the experiment were $4 \mathrm{sq} \mathrm{cm}$ of wood, tin, rexene, formica and ceramic tile pieces.

Results : The disinfectants related to food hygiene and sanitation was studied critically. The concentration of $2 \%$ and $8 \%$ for $\mathrm{Ca}(\mathrm{OC} 1)_{2}$ and $\mathrm{NaOCl}$ respectively would be ideal. Gram negative bacteria $(\boldsymbol{E}$ coli $)$ was more sensitive to $\mathrm{NaOCl}$ than gram positive bacteria (Staph aureus) and gram positive bacteria was more sensitive to $\mathrm{Ca}(\mathrm{OC} 1)_{2}$ than gram negative bacteria on all the five surface materials.. The Germicidal effect of $\mathrm{Ca}(\mathrm{OC} 1)_{2}$ was found better than that of $\mathrm{NaOC} 1$.

Conclusion : Considering the result it can be concluded that both the hypochlorite are more active and effective disinfectant against $\boldsymbol{E}$ coli and Staph aureus. Therefore, to prepare the wholesome and safe food $\mathrm{Ca}(\mathrm{OC} 1)_{2}$ and $\mathrm{NaOC} 1$ are considered as ideal disinfectant for rendering food preparing places and sites free from contamination.

1 Farzana Rahman Lima Assistant Professor Food and Nutrition, NCHE, Dhaka \& PhD Researcher INFS, Dhaka University

${ }^{2}$ Dr. Shahabuddin Ahmed OSD, DGHS, Mohakhali, Dhaka \& MPhil Researcher NIPSOM, Dhaka

Correspondence

Farzana Rahman Lima

Assistant Professor

Food and Nutrition, NCHE, Dhaka

\& PhD Researcher

INFS, Dhaka University

e-mail: farzanalima98@yahoo.com
Key Words: Disinfectants, Hypochlorite, Food hygiene and Sanitation.

\section{Introduction}

The main highways for spread of germs in the home are the hands, food contact surfaces, cleaning cloths and utensils. ${ }^{1}$ In the developing world, for decades, universal access to safe water, food hygiene and sanitation has been seen as the essential step in reducing the preventable communicable disease burden.

Disinfection means to reduce microorganisms of public health importance to a level which is considered safe, based on established parameters, without adversely affecting either the quality of the product or its safety. Disinfection measures may be employed in food processing and preparation. To achieve the required level of disinfection, the chemical must be applied at a certain concentration for a specified amount of time. The efficacy of a chemical used for disinfection rests upon its ability to reduce the contamination level. The standard for contamination reduction of food contact surfaces is generally accepted as $99.9 \%{ }^{2}$

It does not necessary to kill all microorganisms but reduces them to a level which is harmful neither to health nor to the quality of perishable foods. ${ }^{3}$ Russel et al classified the disinfectants as Halogens e.g. sodium hypochlorite, calcium hypochlorite, chlorine gas, iodophors etc., Quaternary ammonium compounds (QAC), Phenols and related compounds, Alcohols (ethanol or isoporpanol), Amphoteric compounds, Hydrogen peroxide, Diguanides, Aldehydes and Ethylene oxide etc. ${ }^{4}$

The selection and the correct use of disinfectants are very important. For better result, in the application of a disinfectant to specific surfaces, appropriate concentration, reaction time, type of contaminating microorganisms, compatibility with the surfaces etc. must be considered. ${ }^{5}$

In Bangladesh various types of disinfectants are available in the market. This study was carried out to observe the activity of disinfectants against various microorganisms adhered to different surface materials in relation with time and concentration and to determine the germicidal effect of those disinfectants.

\section{Materials and Methods}

The study was conducted in the Institute of Nutrition and Food Science (INFS) of Dhaka University, Dhaka. The disinfectants under test were sodium hypochlorite $(\mathrm{NaOCl})$ and calcium hypochlorite $\mathrm{Ca}(\mathrm{OC} 1)_{2}$. Chlorine content of $\mathrm{NaOC} 1$ determined by the titration method was $6.4 \%$ of $8 \%$ solution and of $\mathrm{Ca}(\mathrm{OC} 1)_{2}$ was $0.57 \%$ of $2 \%$ solution. For the test two organisms were selected according to the reference given in the manual of Official methods of analysis. ${ }^{6}$ The microorganisms were Escherichia coli and Staphylococcus aureus bacteria. These two bacteria were obtained from Bangladesh Type Culture Collection, INFS, Dhaka University. Disinfection of 
surfaces for food preparation and processing made of different materials. Surface materials of the experiment were $4 \mathrm{sq} \mathrm{cm}$ of wood, tin, rexene, formica and ceramic tile pieces which used in food preparation areas equipments and apparatus.

Determination of bacteriostatic activity of test disinfectants was done by the Minimum Inhibitory Concentration test (MIC). Qualitative test was performed to determine the time-concentration relationship. Phenolic co-efficient test was conducted to standardize the test disinfectants. Bactericidal activity of the test disinfectants were carried out by qualitative and quantitative suspension test. Determination of qualitative suspension test, the activity of a disinfectant was determined by the presence or absence of the growth in the subculture (Nutrient broth, Agar media). Determination of quantitative suspension test of the disinfectants, after the exposure of bacterial cells to the disinfectant, the number of surviving organisms were compared with the original inoculums size.

The germicidal effect (GE) was calculated using the formula: $\mathrm{GE}=\log$ Nc $-\log N_{D}$, Where Nc = being the number of colony forming units (cfu) in control series and $N_{D}=$ being the number of colony forming units (cfu) in disinfectant series. Practical test method, a control series was maintained in which disinfectant was replaced by distilled water. Only control series were diluted upto $10^{-5}$ dilution to overcome the difficulty uncountable large number of colonies.

\section{Results}

The MIC of $\mathrm{NaOC} 1$ and $\mathrm{Ca}(\mathrm{OC} 1)_{2}$ were determined. It was observed that the lowest concentration which inhibits the growth of organism was $8 \%$ which was the MIC of $\mathrm{NaOC} 1$. Bacterial growth were detected at $1 \%$ concentration of $\mathrm{Ca}(\mathrm{OC} 1)_{2}$ and no growth was detected at $2 \%$, therefore the MIC for $\mathrm{Ca}(\mathrm{OC} 1)_{2}$ was determined as $2 \%$ (Table 1 ).

Table 1 : Determination of $\mathrm{MIC}$ of $\mathrm{NaOCl}$ and $\mathrm{Ca}(\mathrm{OCl})_{2}$

\begin{tabular}{ccccc}
$\begin{array}{c}\text { Concentration } \\
(\%)\end{array}$ & NaOCl & \multicolumn{4}{c}{$\mathrm{Ca}(\mathrm{OCl})_{2}$} \\
1 & Staph aureas & E coli & Staph aureas & E coli \\
2 & + & + & + & + \\
3 & + & + & - & - \\
4 & + & + & - & - \\
5 & + & + & - & - \\
6 & + & + & - & - \\
7 & + & + & - & - \\
8 & + & + & - & - \\
10 & - & - & - & - \\
12 & - & - & - & - \\
+ Presence of growth & - & - & - & - \\
The & & & - Absence of growth
\end{tabular}

The result of phenolic co-efficient of $\mathrm{NaOC} 1$ showed that the growth of the test organisms was absent at $1 / 20$ th concentration with exposure time of 5 minutes. The 1/30th concentration showed negative growth at 10 minutes but positive at 5 minutes. On the other hand, in phenol series bacterial growth was detected at $1 / 50$ th concentration in 5 minutes exposure time, but not in 10 minutes. Hence the phenolic coefficient was calculated as 0.6 . Similarly, in case of $\mathrm{Ca}(\mathrm{OC} 1)_{2}$, the phenolic co-efficient was 0.8 (Table II and Table III).
Table II: Determination of Phenolic co-efficient of $\mathrm{NaOCl}$

Growth in subculture

Disinfectant $\quad 5 \mathrm{~min} \quad 10 \mathrm{~min} \quad 15 \mathrm{~min}$

$\begin{array}{ccccccc}\text { concentration } & \text { Staph aureas } & \text { E coli } & \text { Staph aureas } & \text { E coli } & \text { Staph aureas } & \text { E coli } \\ 1 / 20 & - & - & - & - & - & - \\ 1 / 30 & + & + & - & - & - & - \\ 1 / 40 & + & + & + & + & - & - \\ 1 / 50 & + & + & + & + & + & + \\ 1 / 60 & + & + & + & + & + & +\end{array}$

Phenol

\begin{tabular}{lcccccc} 
concentration & & $5 \mathrm{~min}$ & \multicolumn{3}{c}{$10 \mathrm{~min}$} & $15 \mathrm{~min}$ \\
$1 / 20$ & - & - & - & - & - & - \\
$1 / 30$ & - & - & - & - & - & - \\
$1 / 40$ & - & - & - & - & - & - \\
$1 / 50$ & + & + & - & - & - & - \\
$1 / 60$ & + & + & + & + & - & - \\
+ &
\end{tabular}

Table III : Determination of Phenolic co-efficient of $\mathrm{Ca}(\mathrm{OCl})_{2}$

\begin{tabular}{|c|c|c|}
\hline & & bculture \\
\hline Disinfectant & $5 \min$ & $10 \mathrm{~min}$ \\
\hline
\end{tabular}

concentration Staph aureas E coli Staph aureas Ecoli Staph aureas E coli

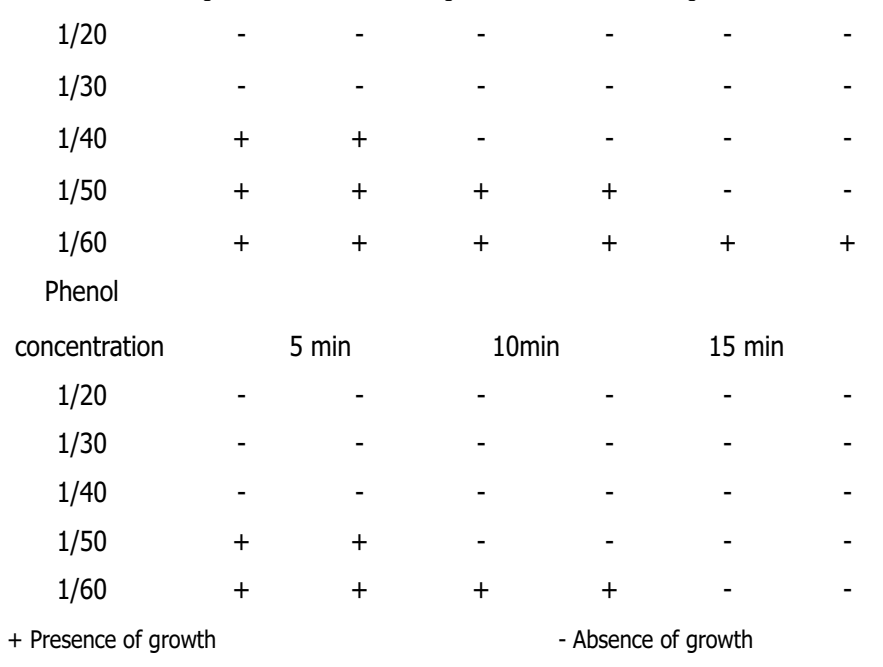

The concentration of disinfectants was constant according to their MIC values and a little above. The MIC of NaOC1 i.e. $8 \%$ showed no effect after 5 minutes exposure time against the organisms. Within 10 minutes $8 \% \mathrm{NaOCl}$ was found cidal against Staph aureus. But in the same concentration the cidal activity was not found within 15 minutes time against $E$ coli. However, the cidal activity against $E$ coli was detected within 25 minutes. Within 10 to 30 minutes exposure time $10 \% \mathrm{NaOC} 1$ was effective against both the organisms. The higher concentration of $\mathrm{NaOC1}(12 \%)$ showed cidal effect against both the organisms within 5 minutes. At $2 \%$ i.e. the MIC value of $\mathrm{Ca}(\mathrm{OC} 1)_{2}$, the growth of Staph aureus and $E$ coli were not positive after 5 minutes (Table IV). 


\begin{tabular}{|c|c|c|c|c|c|c|}
\hline \multirow{2}{*}{\multicolumn{2}{|c|}{$\begin{array}{cc}\text { Test bacteria } & \begin{array}{c}\text { Concentration of } \\
\text { disinfectant } \\
\text { solution }(\%) \\
\mathrm{Ca}(\mathrm{OC} 1)_{2}\end{array}\end{array}$}} & \multicolumn{5}{|c|}{ Time (min) } \\
\hline & & 5 & 10 & 15 & 25 & 30 \\
\hline \multirow[t]{3}{*}{ Staph aureus } & 8 & + & - & - & - & - \\
\hline & 10 & + & - & - & - & - \\
\hline & 12 & + & - & - & - & - \\
\hline \multirow[t]{3}{*}{ E coli } & 8 & + & + & + & - & - \\
\hline & 10 & + & - & - & - & - \\
\hline & 12 & - & - & - & - & - \\
\hline \multirow[t]{2}{*}{ Test bacteria } & $\begin{array}{l}\text { entration of } \\
\text { sinfectant }\end{array}$ & & & ime ( $m$ & & \\
\hline & $(\%) \mathrm{Ca}(\mathrm{OCl})_{2}$ & 5 & 10 & 15 & 25 & 30 \\
\hline \multirow[t]{3}{*}{ Staph aureus } & 2 & - & - & - & - & - \\
\hline & 4 & - & - & - & - & - \\
\hline & 6 & - & - & - & - & - \\
\hline \multirow[t]{3}{*}{ E coli } & 2 & - & - & - & - & - \\
\hline & 4 & - & - & - & - & - \\
\hline & 6 & - & - & - & - & - \\
\hline \multicolumn{4}{|c|}{ + Presence of growth } & \multicolumn{3}{|c|}{ - Absence of growth } \\
\hline
\end{tabular}

The quantitative suspension test of $\mathrm{NaOC} 1$ and $\mathrm{Ca}(\mathrm{OC} 1)_{2}$ in which $1 \%$ concentration were used against Staph aureus. In case of Staph aureus the germicidal effect of $\mathrm{NaOC} 1$ and $\mathrm{Ca}(\mathrm{OC} 1)_{2}$ were 1.80 and 1.29 after 5 minutes respectively (Table $\mathrm{V}$ )

Table V : Quantitative suspension test

Number of colony forming units (cfu)

Dilution of In control series In disinfectant series Germicidal effect

subculture

\begin{tabular}{|c|c|c|c|c|c|c|}
\hline \multicolumn{2}{|l|}{ Quantitative } & Number & Log & Number & $\log$ & $=\log N_{C}-\log N_{D}$ \\
\hline \multicolumn{7}{|l|}{ suspension } \\
\hline \multirow[t]{6}{*}{ test of $\mathrm{NaOCI}$} & $10^{0}$ & tntc & - & tntc & - & $=(4+2.692)-(3+1.886)$ \\
\hline & $10^{-1}$ & tntc & - & tntc & - & $=6.692-4.886$ \\
\hline & $10^{-2}$ & tntc & - & tntc & - & $=1.80($ After $5 \mathrm{~min})$ \\
\hline & $10^{-3}$ & tntc & - & 64 & 1.886 & \\
\hline & $10^{-4}$ & 492 & 2.692 & 9 & 0.954 & \\
\hline & $10^{0}$ & tntc & - & tntc & - & Germicidal effect \\
\hline Quantitative & $10^{-1}$ & 456 & 2.659 & 23 & 1.361 & $=\log N_{C}-\log N_{D}$ \\
\hline suspension & $10^{-2}$ & 16 & 1.204 & 10 & 1 & $=(1+2.659)-(1+1.361)$ \\
\hline \multirow[t]{2}{*}{ test of $\mathrm{Ca}(\mathrm{OCI})_{2}$} & $10^{-3}$ & 17 & 1.230 & 0 & - & $=3.659-2.361$ \\
\hline & $10^{-4}$ & 6 & 0.778 & 0 & - & $=1.29$ (After $5 \mathrm{~min})$ \\
\hline
\end{tabular}

tntc $=$ too numerous to count

$\mathrm{N}_{\mathrm{C}}=$ Number of $\mathrm{cfu}$ in control series $\mathrm{N}_{\mathrm{D}}=$ Number of cfu in disinfectant series

Table VI : Germicidal effect of $\mathrm{NaOC} 1$ and $\mathrm{Ca}(\mathrm{OCI})_{2}$ against $E$ coli and Staph aureus on different surface materials

\begin{tabular}{lcccc} 
Test surface materials & \multicolumn{2}{c}{ NaOCI } & \multicolumn{2}{c}{$\mathbf{C a}(\mathbf{O C I})_{2}$} \\
& E coli & Staph aureus & E coli & Staph aureus \\
Wood & 5.21 & 5.06 & 5.56 & 5.92 \\
Tin & 5.73 & 5.27 & 5.3 & 5.86 \\
Rexene & 5.53 & 5.24 & 5.38 & 5.70 \\
Formica & 5.76 & 5.31 & 5.30 & 5.91 \\
Ceramic tiles & 5.51 & 5.27 & 5.35 & 5.76
\end{tabular}

The germicidal value of $\mathrm{NaOCI}$ and $\mathrm{Ca}(\mathrm{OCI})_{2}$ against $E$ coli and Staph aureus on different surface materials were observed. On formica surface the GV of $\mathrm{NaOCl}$ against E coli and Staph aureus was the highest i.e. 5.76 and 5.31 respectively. On the other hand, on wood surface the GV of $\mathrm{NaOCl}$ against $E$ coli and Staph aureus was the lowest i.e. 5.21 and 5.06 respectively. But on wood surface the GV of $\mathrm{Ca}(\mathrm{OCl})_{2}$ against both $E$ coli and Staph aureus was the highest i.e. 5.56 and 5.92 respectively (Table VI)

\section{Discussion}

In the present study the MIC of $\mathrm{NaOCl}$ against the test organisms i.e. Staph aureus and E coli was $8 \%$ in which the chlorine content was $6.4 \%$. But from the literature ${ }^{9}$ it was observed that $1-15 \%$ concentration of $\mathrm{NaOC} 1$ contains $1-5 \%$ available chlorine which was more than the $\mathrm{NaOC} 1$ under test i.e. 6.4\%. Marufa and Sarwar also obtained almost similar results i.e. the estimated available chorine content was $5-8 \%$. Strength of the hypochlorites i.e. the chlorine content of it depends basically on the producers. ${ }^{7,8}$ In comparison, it was observed that the MIC of $\mathrm{Ca}(\mathrm{OC} 1)_{2}$ is lower than that of $\mathrm{NaOCI}$, where the available chlorine also varied which was $0.57 \%$ and $6.4 \%$ respectively. It has been reported by Hugo and Russell that the hypochlorites could be inactivated by nutrient broth. ${ }^{4}$ But in the present study, it was observed that both sodium hypochlorite and calcium hypochlorite were not inactivated by the interference of nutrient broth media.

Phenol co-efficient test also known as Rideal-Walker test was established only as an attempt to characterize the antimicrobial chemical agents which was considered as the reference standard. ${ }^{5,9}$ The results of phenolic co-efficient showed that the germicidal values varied between the two hypochlorites. that the phenolic co-efficient of $\mathrm{Ca}(\mathrm{OC} 1)_{2}$ was higher i.e. 0.8 than that of $\mathrm{NaOC} 1$ i.e. 0.6.

In qualitative suspension test of $\mathrm{NaOC1}$, it was observed that $12 \%$ solution was the most effective as bactericidal. The results against the two test organisms i.e. Staph aureus and $E$ coli were varied. It was observed that $\mathrm{NaOC1}$ solution was not cidal to $E$ coli at $8 \%$ concentration even in 15 minutes and at $10 \%$ in 5 minutes. ${ }^{10}$ The qualitative suspension test of $\mathrm{Ca}(\mathrm{OC} 1)_{2}$ showed the cidal action against both the bacteria within 5 minutes. The result was recorded from the visual observation on the turbidity, both of broth and the growth on agar surface. From the results it was evident that the $\mathrm{Ca}(\mathrm{OCI})_{2}$ was more efficient than $\mathrm{NaOCl}$. The results of the quantitative suspension test or the germicidal value of $\mathrm{NaOC} 1$ and $\mathrm{Ca}(\mathrm{OC} 1)_{2}$ were 1.80 and 1.29 after 5 minutes respectively. Therefore, it was evident that $\mathrm{NaOC} 1$ showed stronger germicidal action than $\mathrm{Ca}(\mathrm{OC} 1)_{2}$ against Staph aureus.

The mean of germicidal values (GV) of $\mathrm{NaOC} 1$ after 10 and 15 minutes on formica surface against Staph aureus and E coli were the highest. Due to the smooth surface of formica, NaOC1 worked best against both the bacteria. On other hand, the germicidal values of $\mathrm{NaOC1}$ against $E$ coli and Staph aureus on wood surface were the lowest among the five surface materials due to porous structure. ${ }^{11}$ The porosity and the rough surface of wood would hide more bacteria and thus escaped from the disinfection action. The rough surface of rexene due to its embossed design, gave the GV lower against both the bacteria. The embossed design of rexene helped large number of the bacteria to harbour on it, which the hypochlorite solution ( $\mathrm{NaOC} 1$ ) could not reach properly. Both E coli and Staph aureus on tin surface, the GV of NaOC1 were second highest i.e. next to formica. Surface of tin was not rough but not as 
smooth as formica, so the disinfection action on tin surface was moderate. Throughout the test in was observed that $E$ coli was more sensitive to NaOC1 than Staph aureus on all the five surface materials. On the other hand the $\mathrm{GV}$ of $\mathrm{Ca}(\mathrm{OC} 1)_{2}$ was highest against both $E$ coli and Staph aureus on wood surface. In spite of porous structure of wood, $\mathrm{Ca}(\mathrm{OC} 1)_{2}$ showed highest GV. So, it seemed that $\mathrm{Ca}(\mathrm{OC} 1)_{2}$ solution reached the pores due to its reduced surface tension and killed the bacteria. On the contrary, the $\mathrm{GV}$ of $\mathrm{Ca}(\mathrm{OC} 1)_{2}$ against $E$ coli on tin and fromica surface were the lowest among the five surface materials. Against Staph aureus, the rough surface due to embossed design of rexene, the disinfection action of $\mathrm{Ca}(\mathrm{OC} 1)_{2}$ was resistant and made the GV lowest. The overall GV of $\mathrm{Ca}(\mathrm{OC} 1)_{2}$ against Staph aureus on all the five surface materials were higher than against $E$ coli.

\section{Conclusion}

The disinfectants related to food hygiene and sanitation were studied critically. The concentration of $2 \%$ and $8 \%$ for $\mathrm{Ca}(\mathrm{OC} 1)_{2}$ and $\mathrm{NaOC1}$ respectively would be ideal. Gram negative bacteria was more sensitive to $\mathrm{NaOC} 1$ than gram positive bacteria and gram positive bacteria was more sensitive to $\mathrm{Ca}(\mathrm{OC} 1)_{2}$ than gram negative bacteria on all the five surface materials. The germicidal effect of $\mathrm{Ca}(\mathrm{OC} 1)_{2}$, was found better than that of $\mathrm{NaOC1}$. Both the hypochlorites are suitable disinfectants for food preparation related objects, sites and places.

\section{References}

1. WHO. The global Burden of Disease: 2004, update 2008. Available from:http:// www.who.int/healthinfo/global_burden_disease/2004_report_update/en/index.

2. AOAC International Official Methods of Analysis. AOAC International, Gaithersburg, MD. 2009.

3. Maurer IM. 'Sterilization and Disinfection'. In Food Poisoning and Food Hygiene, Hobbs BC and Gilbert RJ. 4th Edition, Edward Arnold Ltd, London. 1978; 211.

4. Russell AD, Hugo WB and Ayliffe GAJ. 'Principles and Practice of Disinfection, Preservation and Sterilization'. Blackwell Scientific Publication, Oxford, London. 1982; p 224.

5. Reybrouck G. 'The Evalution of the Antimicrobial Activity of Disinfectants'. In Principles and Practice of Disinfection, Preservation and Sterilization, edited by Russell AD, Hugo WB and Ayliffe GAJ. Blackwell Scientific Publications. Oxford, London. 1982; pp 134-155.

6. Dychdala GR. 'Chlorine and Chlorine Compounds'. In Disinfection Sterilization and Preservation, Seymour SB. 3rd Edition, Lea and Febiger, Philadelphia. 1986.

7. Marufa AK. 'Studies on the efficacy of commercial cleaning agents and disinfectants in the maintenance of food hygiene and sanitation'. MSc Thesis, Institute of Nutrition and Food Science, DU. 1995.

8. Sarwar MS. 'Studies on household disinfectants'. MSc Thesis, Applied Chemistry Dept, DU. 1994.

9. Cremieux A and Fleurette J. 'Methods of Testing Disinfectant.' In Disinfection, Sterilization and Preservation. Seymour SB, 3rd Edition. Philadelphia. 1983; pp 918-19.

10. Pleczer JR, Chan ECS and Krieg NR. In 'Microbiology', 5th Edition, McGraw-Hill Publishing Company, New York. 1986; pp 106-107, 144-145.

11. Hobbs BC and Gilbert RJ. 'Food Poisoning and Food Hygiene', 4th Edition, Edward Arnold Ltd, London. 1978; pp 189-193. 